\title{
Deuterium Oxide-induced Reversion of Naegleria gruberi Flagellates
}

\author{
By T. M. PRESTON AND D. S. O'DELL \\ Department of Zoology, University College London, Gower Street, \\ London, WC I E $6 B T$
}

(Received 3 October 1972)

\begin{abstract}
SUMMARY
A bead column technique is described for the separation of Naegleria gruberi flagellates from amoebae and cysts. It is shown that $\mathrm{D}_{2} \mathrm{O}$ induces a rapid reversion of these flagellates to amoebae, and the behaviour and structure of the reverting cells is described. The amoebae are viable in high concentrations of $\mathrm{D}_{2} \mathrm{O}$, and when returned to suspension in $\mathrm{H}_{2} \mathrm{O}$ readily retransform to the flagellate stage. The reversion of flagellates to amoebae is insensitive to cycloheximide, but the subsequent retransformation to flagellate can be prevented by both actinomycin D and cycloheximide.
\end{abstract}

\section{INTRODUCTION}

The soil protozoon Naegleria gruberi (Schardinger) can exist in three states: as an amoeba which feeds and divides; as a flagellate which swims strongly for a few hours but does not feed or divide; and as a cyst. The transformation from amoeba to flagellate can readily be controlled in the laboratory and provides a particularly amenable model for the study of morphogenesis in unicellular eukaryotes (Fulton, 1970). The process is temperature dependent and takes about $100 \mathrm{~min}$ at $27^{\circ} \mathrm{C}$; it can be prevented by inhibitors of RNA and protein synthesis (Balamuth, 1965; Preston \& O'Dell, 197I ; Yuyama, I97I). The reversion of flagellate to amoeba is very much faster and, as will be described here, shows no comparable sensitivity to these inhibitors. Spontaneous reversion of individual flagellates, which occurs sporadically and can be increased by, for example, applying mild shearing forces or adding certain fixatives, can create difficulties for the experimentalist. In this paper, methods are described which enable the easy production and fixation of populations consisting entirely of flagellates or amoebae, and it will also be shown that deuterium oxide is an inducer of a general and rapid reversion to the amoeboid stage. These techniques have enabled a number of observations to be made on the reversion process and the transformation back to flagellate.

\section{Protozoa}

\section{METHODS}

Naegleria gruberi (stock 15I8/I C, Cambridge Culture Collection) was maintained at $25{ }^{\circ} \mathrm{C}$ in monoxenic culture with Klebsiella aerogenes on $0.2 \%(\mathrm{w} / \mathrm{v})$ peptone agar plates. When cells were required in the amoeboid phase cultures were harvested within $20 \mathrm{~h}$ of inoculation as previously described (Preston \& O'Dell, 197I). Extension of the incubation period beyond $48 \mathrm{~h}$ resulted in encystment of most of the amoebae; a pure, viable cyst suspension could be readily secured if residual trophic cells were removed by mild detergent lysis with Triton X $100,0.05 \%(\mathrm{v} / \mathrm{v})$ in 2 mm-tris (Fulton, 1970) before harvesting. Incubation of amoebae suspended in 2 mM-tris, $\mathrm{pH} 7.5$, in a shaking water bath at $27^{\circ} \mathrm{C}$ resulted 


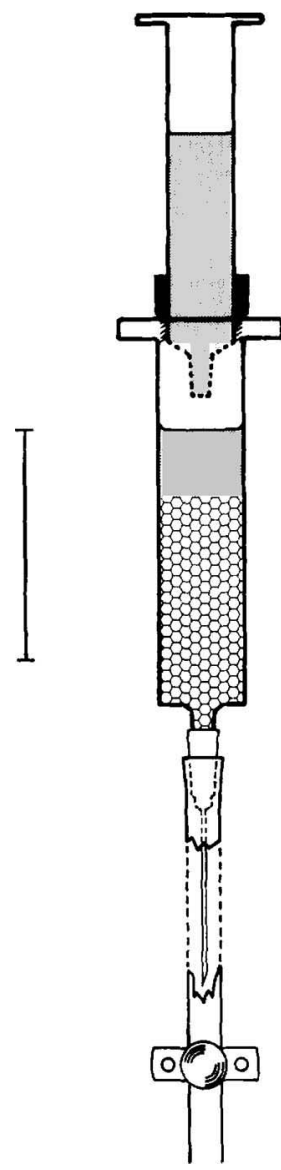

Fig. I Glass bead column used in the separation of flagellate Naegleria gruberi from other stages. For details of assembly, see text. Scale marker represents $5 \mathrm{~cm}$.

in their transformation to the flagellate stage. The synchrony of this change was high ( 80 to $90 \%$ ) but not perfect. Therefore in order to obtain pure suspensions of flagellate cells other procedures were tested.

\section{Flagellate separation methods}

Density gradient centrifugation. Continuous gradients of o to $20 \%(\mathrm{w} / \mathrm{v})$ Ficoll in $2 \mathrm{~mm}-$ tris were prepared and samples of populations of mixed stages carefully layered on top. After brief periods of centrifugation at 500 to $2000 \mathrm{~g}$ at room temperature, samples were drawn off the gradients and examined by phase-contrast microscopy.

Capillary tube migration. The capillary region of a Pasteur pipette was drawn into zigzags and sealed distally. Amoebae and flagellates were suspended in $2 \mathrm{~mm}$-tris and introduced into the wide end which was then sealed and the whole stood pointing upwards. At intervals the pipette was examined by dark ground microscopy. The contents of the capillary region could be isolated by snapping the pipette in the transition region.

Glass bead column (Fig. I). A Io ml plastic syringe without the piston was used to support a column of $2 \mathrm{~mm}$ diameter glass beads. A $5 \mathrm{ml}$ syringe was inserted into the top of this to act as a reservoir. Layers of parafilm provided an airtight seal between the two barrels. 
Flow rate of liquid through the column was controlled by a burette clip on silicone rubber tubing leading off a 2I-gauge needle attached to the larger syringe barrel. Such a column had an average void volume of $3.5 \mathrm{ml}$ and a glass surface area of the order of $15 \mathrm{~cm}^{2}$. For an experiment the column was thoroughly washed with $2 \mathrm{~m}$ M-tris, then 3 to $4 \mathrm{ml}$ of harvested cells (about $3 \times 10^{6}$ cells $/ \mathrm{ml}$ ) were layered on to it. These cells were carefully drawn into the bead matrix, and then fluid flow stopped for $15 \mathrm{~min}$ to allow the amoebae to attach to the glass surface. The column was then carefully eluted with buffer flowing gently under gravity for an hour to remove any unattached cells and bacteria, the eluent being monitored microscopically. Elution was then discontinued and the column allowed to stand until the buffer above the bead bed became turbid - usually after a period of $150 \mathrm{~min}$ at room temperature. Then $5 \mathrm{ml}$ of buffer were drawn off the column and checked microscopically to estimate the percentage phenotype distribution of the cells. A sample of this suspension was fixed by dilution I : Io with commercial formalin (approx. $40 \%$ formaldehyde), and used after further dilution I : 25 with isotonic saline to estimate cell number in a Coulter Counter, Model ZB I (I40 $\mu \mathrm{m}$ aperture, $500 \mu 1$ sampling volume, aperture current $4 \mathrm{~mA}$ and amplification 2 ).

\section{Electron microscopy of reverting cells}

Flagellates were drawn off a glass bead column into two Io $\mathrm{ml}$ graduated centrifuge tubes. Deuterium oxide ( $99.7 \%$ minimum isotopic purity, B.D.H. Chemicals Ltd, Poole, Dorset) was added to these to final concentrations of 38 and $78 \%(\mathrm{v} / \mathrm{v})$ respectively. Ten minutes later the cells were fixed by addition of $25 \%(\mathrm{v} / \mathrm{v})$ glutaraldehyde (Taab Laboratories, Reading, Berkshire) to give a final concentration of $2.5 \%(\mathrm{v} / \mathrm{v})$. After $\mathrm{I} 8 \mathrm{~h}$ at $20{ }^{\circ} \mathrm{C}$ the fixative was removed by thorough washing in 2 mM-tris at $\mathrm{pH} 7 \cdot 5$. The cells were postfixed for $\mathrm{I} 4 \mathrm{~h}$ in $\mathrm{I} \%(\mathrm{w} / \mathrm{v}) \mathrm{OsO}_{4}$ in 2 mM-tris, $\mathrm{pH} 7.5$, then immersed in $0.5 \%(\mathrm{w} / \mathrm{v})$ aqueous uranyl acetate for $48 \mathrm{~h}$. Dehydration was effected with graded water-ethanol mixtures and the cells were subsequently embedded in araldite resin. Sections showing silver/grey interference colours, prepared on a Huxley ultramicrotome, were collected on uncoated copper grids and stained in lead citrate. They were then examined in an AEI EM6B electron microscope operated at an accelerating voltage of $60 \mathrm{kV}$ with an objective aperture of $50 \mu \mathrm{m}$. Images were recorded on Ilford N6o plates and nominal instrument magnifications were corrected to a standard by means of a diffraction grating replica $\left(2 \cdot 16^{-1} \mu \mathrm{m}\right.$ interval). Measurements on individual electron micrographs were made by means of a microdensitometer (Joyce-Loebl, MK IIIc) calibrated against the diffraction grating image recorded at the same magnification.

\section{Light microscopy and filming}

Routine microscopy was carried out with both Leitz and Zeiss (Oberkochen) equipment. Phase-contrast micrographs were recorded on Ilford $\mathrm{HP}_{4}$ emulsion using Zeiss $\times \mathrm{IOO}$, N.A. $1 \cdot 3$ and $\times 40$, N.A. I $\cdot 0$ objectives, a $547 \mathrm{~nm}$ interference filter being inserted into the optical path below the condenser. An electrically driven Bolex I $6 \mathrm{~mm}$ camera loaded with Ilford Mark $\mathrm{V}$ emulsion was used to film through a Zeiss photomicroscope bearing a $\times 6.3$ N.A. $0 \cdot 2$ objective. Filming speed was $I 6$ frames/s and the microscope was fitted with an interference heat filter. For each trial $\mathrm{D}_{2} \mathrm{O}$ was added to a flagellate suspension and gently mixed. A drop was withdrawn and placed on a microscope slide without the addition of a coverslip. By adiustment of the height of the condenser below the specimen stage, good dark ground illumination was produced by the field stop of a suitable phase annulus. With practice filming could be commenced within $30 \mathrm{~s}$ of the addition of $\mathrm{D}_{2} \mathrm{O}$ to the flagellates. Films were analysed by plotting the tracks of individual cells from frame to frame. 


\section{Fixation of flagellates}

Preliminary experiments showed that some fixatives were unsatisfactory, as flagellates were able to revert at least partially to amoebae during the brief period before fixation was complete. For example, when a culture consisting entirely of flagellates was mixed with an equal volume of $12 \%$ acrolein, cells could be seen to alter their shape on contact with the fixative and reverting cells were found in the fixed material. Chang (1958) reported that silver nitrate fixed flagellates, but in the present study zinc ions were tested, following the observation that they stabilize some membranes during cell fractionation procedures (Warren, Glick \& Nass, I966). Accordingly, o.0oI $\mathrm{M}-\mathrm{ZnCl}_{2}$ was applied to Naegleria flagellates for I 5 to $30 \mathrm{~min}$, and good preservation resulted, without emission of pseudopodia or other signs of reversion to the amoeboid form. The cells became, however, rounder than unfixed flagellates.

\section{Separation techniques}

\section{RESULTS}

In preliminary trials, attempts were made to separate the cyst, flagellate and amoeba stages of Naegleria gruberi by centrifugation at low speeds in a Ficoll density gradient. This method was never entirely satisfactory; first, because there was too much overlap in density between the three stages; secondly, because the flagellates tended to revert during the process; and thirdly, because of some cell loss by lysis of the motile stages.

The glass pipette technique enabled flagellates, by virtue of their much greater mobility, to migrate away from untransformed amoeboid cells. Phenotype separation by this method was perfect and distally the capillary contained only flagellates, but the yield was low.

The glass bead column method, by exploiting the difference in adhesion properties between the two motile stages of Naegleria gruberi, proved to be a far more efficient procedure for the isolation of flagellates. The success of this technique depended on gentle elution of the column. Too high a flow rate during harvesting resulted in amoebae detaching from their glass substrate and being drawn off with the flagellates. Provided that elution of the column after the layering on and settling of the cell suspension was thorough, any cysts present were either washed clear or became firmly trapped in the bead bed. A suitable flow rate for our column was $2 \mathrm{ml} / \mathrm{min}$. Using a glass bead column of the given dimensions and starting with $10^{7}$ cells a yield of $10^{6}$ flagellates could be routinely obtained and contamination of this by other stages was difficult to detect. Preparations of cells were initially contaminated with Klebsiella aerogenes from the culture plates, but the bacteria were readily eliminated by chloramphenicol treatment. Since our strain of $N$. gruberi is impermeable to this drug unless treated with agents such as polymyxin B (Preston \& O’Dell, 197I), it was possible to treat a mixture of amoebae and bacteria selectively with chloramphenicol.

\section{The effects of deuterium oxide}

Induction of flagellate reversion. After harvesting from the column, control flagellates showed a variable degree of activity; most moved rapidly and swam flagella foremost in a straight line or with frequent changes of direction. An occasional cell showed the first sign of reversion, a change of locomotory pattern from linear progression to constant movement along a circular path, or rotation about its axis.

The overall effect of adding $\mathrm{D}_{2} \mathrm{O}$ to the flagellates was to cause a general and rapid reversion to the amoeboid form. In high concentrations ( 50 or $75 \%$ ), within $30 \mathrm{~s}$ half or more of the cells were spinning, although a decreasing proportion maintained typical 
flagellate locomotion for a little longer. By $2 \mathrm{~min}$, virtually all cells demonstrated stages of reversion such as the change in swimming pattern, the emission of pseudopodia and attachment to the substrate. As far as could be seen $\mathrm{D}_{2} \mathrm{O}$ did not introduce any new characters into the reversion process, but merely induced its rapid onset.

Twenty-five per cent $\mathrm{D}_{2} \mathrm{O}$ was less effective in causing reversion. After $30 \mathrm{~s}$, only a few cells were obviously reverting and even after $5 \mathrm{~min}$ there was still a roughly equal mixture of reverting cells and apparently normal and active flagellates. Reversion, when it occurred, seemed to follow the standard pattern.

Viability of amoebae in $\mathrm{D}_{2} \mathrm{O}$. Suspensions of flagellates without amoebae or cysts were pipetted into $\mathrm{D}_{2} \mathrm{O}-\mathrm{H}_{2} \mathrm{O}$ mixtures at final $\mathrm{D}_{2} \mathrm{O}$ concentrations of 25 to $95 \%$, and the flasks left for 2 days at room temperature. After this time viable amoebae, with active contractile vacuoles, were found in all concentrations of $\mathrm{D}_{2} \mathrm{O}$. In $90 \%$ or $95 \% \mathrm{D}_{2} \mathrm{O}$, however, the amoebae were unable to attach normally to a glass substrate, although streaming movements could be seen in the cytoplasm and active pseudopodia were formed. Occasionally, minor adhesions were made to the substrate and filopodia trailed behind. When these amoebae were plated out under our standard conditions, the growth of normal cultures demonstrated the lack of any permanent lesion induced by $\mathrm{D}_{2} \mathrm{O}$.

\section{The reversion process in deuterium oxide-treated flagellates}

Observations on living cells. Active streaming in the cytoplasm was suppressed in the flagellate stage, but recommenced rapidly after the administration of $\mathrm{D}_{2} \mathrm{O}$ causing symmetry to be lost as small pseudopodia erupted at any point on the cell surface (Fig. 3,4). At this stage if the cell collided with the glass substrate it adhered briefly. Eventually the organism adhered to the glass strongly enough to nullify the resultant of the flagellar strokes. This marked a transition point in the cell's locomotory behaviour, as although the flagella continued to beat, the cell now moved by amoeboid locomotion. Two further events could be seen as reversion approached completion. In the active flagellate the rhizoplast (Fig. 5, 7) inserted at the basal bodies transmitted slight waves from the flagella to the nucleus causing this organelle to undergo small displacements. As reversion was completed and amoeboid movement commenced, the nucleus was still restrained by its rhizoplast connexion from being drawn freely into the path of cytoplasmic flow, and this antagonism between the rhizoplast anchorage and the cytoplasmic streaming could deform the nucleus into a conoid (Fig. 5). A further stage in the process of phenotype reversion was marked when the connexion broke between the rhizoplast and the nucleus so that the latter could be moved freely by the flowing cytoplasm. Those mitochondria which in flagellates were aligned along the rhizoplast (Fig. 2) became dispersed in the cytoplasm.

The other and more readily observable event was flagellar loss, which usually occurred in one of two ways. Either a bleb appeared at the distal end of the flagellum and, as it increased in size, the length of the flagellum decreased until the bleb became incorporated in the cytoplasm of the cell; or, during a posterior stroke, a flagellum collided with the cell membrane, rapidly penetrated it and continued to beat for a short time within the cytoplasm (Fig. 6).

Ultrastructure. Schuster (I963) and Dingle \& Fulton (I966) have given a general account of the fine structure of the developing flagellate stage; attention here was confined to changes in the mastigont system during reversion. The only difference between the flagellate samples fixed after Io min in $38 \%$ or $78 \%(\mathrm{v} / \mathrm{v}) \mathrm{D}_{2} \mathrm{O}$ concerned the distribution of their flagella. Cells treated with the lower concentration of $\mathrm{D}_{2} \mathrm{O}$ had normal, external flagella, whereas those exposed to the higher concentration had at least one flagellum, if not both (or all in 
T. M. PRESTON AND D. S. O'DELL
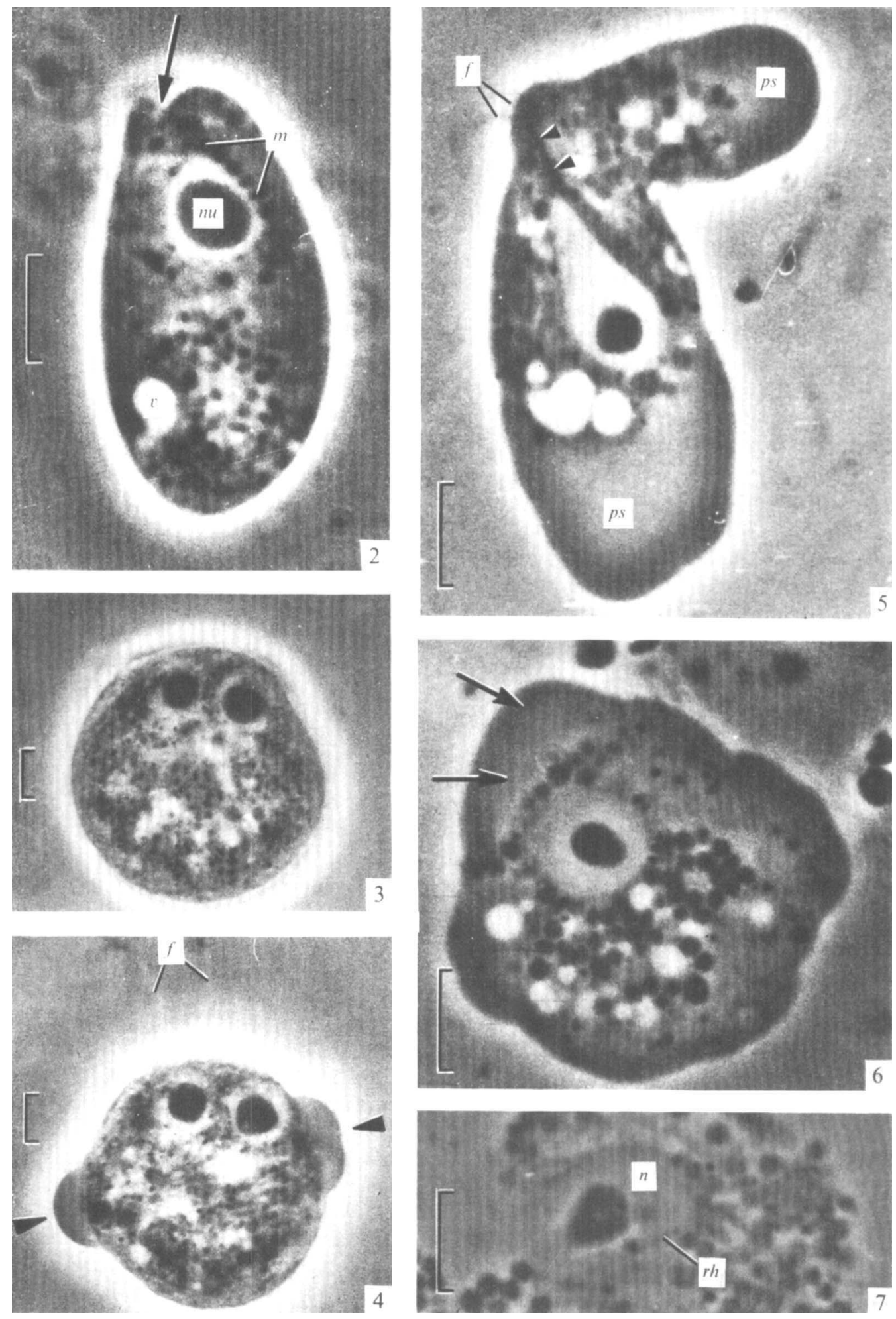
the case of occasional multiflagellate cells), withdrawn into their cytoplasm. Furthermore the flagella, on entering the cell during $\mathrm{D}_{2} \mathrm{O}$-induced transformation, lost their enclosing membrane (Fig. 9). No complete internal flagellum was seen; only exposed axonemes were present within the cytoplasm even in cells that had not completed the intake of their flagellar complement (Fig. 8). There were indications of a loss of spatial organization within some of these axonemes although the basal body-rhizoplast complex was still intact (Fig. I I).

The close spatial relationship existing in Naegleria gruberi flagellates between the rhizoplast and the nuclear envelope, evident by light microscopy, was confirmed by the electron microscope (Fig. I0), but the increase in resolution did not reveal the structural basis for the mechanical strength of this association. Optical density profiles along rhizoplasts in cells treated with $\mathrm{D}_{2} \mathrm{O}$ revealed a major period of $\mathrm{I} 9 \mathrm{~nm}$ in the cross-striations. This period was the same whether flagella were external or internal.

Cycloheximide: lack of effect on reversion. Flagellates were treated with $\mathrm{D}_{2} \mathrm{O}$ in the presence of $10 \mu \mathrm{g} / \mathrm{ml}$ cycloheximide, an inhibitor of protein synthesis which penetrates Naegleria gruberi amoebae without difficulty and inhibits the initial transformation into flagellate (Preston \& O'Dell, I97I). Reversion proceeded as before, with the onset of streaming, eruption of pseudopodia and loss of flagella.

Retransformation of reverted cells. When flagellates had reverted to amoebae, the latter on removal from $\mathrm{D}_{2} \mathrm{O}$ retransformed to flagellates as readily and under the same conditions as untreated amoebae did, and showed similar susceptibility to antibiotics. Under our standard transformation conditions (Preston \& O'Dell, I $97 \mathrm{I})$ actinomycin D $(50 \mu \mathrm{g} / \mathrm{ml})$ and cycloheximide (10 $\mu \mathrm{g} / \mathrm{ml}$ ) both inhibited the production of flagellates.

\section{DISCUSSION}

The ability of Naegleria gruberi to survive in an active amoeboid stage in $95 \% \mathrm{D}_{2} \mathrm{O}$ is not unique but is none the less notable, as sudden immersion in this concentration is toxic for most protozoa (see reviews by Thomson, 1963; Flaumenhaft, Bose, Crespi \& Katz, I965; Katz \& Crespi, I970). In this concentration the amoebae were abnormal in that they displayed a reduced ability to attach to a glass substrate, but the contractile vacuole continued to function under circumstances which reversibly inhibit that of Paramecium, Blepharisma, Discophrya and Carchesium (Gaw, I936; Kitching \& Padfield, I960). Cytoplasmic streaming

Key to symbols: $a x=$ axoneme, $b=$ basal body, $f=$ flagellum, $m=$ mitochondrion, $n=$ nucleus, $n u=$ nucleolus, $p s=$ pseudopodium, $r h=$ rhizoplast, $v=$ contractile vacuole.

Fig. 2. to 7. Naegleria gruberi. Phase-contrast micrographs of unfixed normal and reverting flagellates. All scale markers represent $5 \mu \mathrm{m}$.

Fig. 2. Normal flagellate. The flagella, out of the plane of focus, are inserted in an apical depression (arrowed) from which a line of mitochondria lead posteriorly adjacent to one side of the nucleus.

Fig. 3. Binucleate flagellate, and Fig. 4, the same cell io s later at the onset of cytoplasmic streaming and pseudopodia production (marked by large arrowheads).

Fig. 5. Reverted flagellate progressing along the substrate in amoeboid fashion. The nucleus, anchored by the rhizoplast (small arrowheads) to the basal bodies, is being drawn into a conoid by the flowing cytoplasm of the leading pseudopodium.

Fig. 6. The flagella have been withdrawn into the amoeboid organism and the mastigont system has now lost its physical connection with the cell membrane. A flagellar axoneme (arrowed) is still visible within the cytoplasm.

Fig. 7. The same cell some minutes later lysed to demonstrate the intimate association between the rhizoplast and the nuclear envelope. 


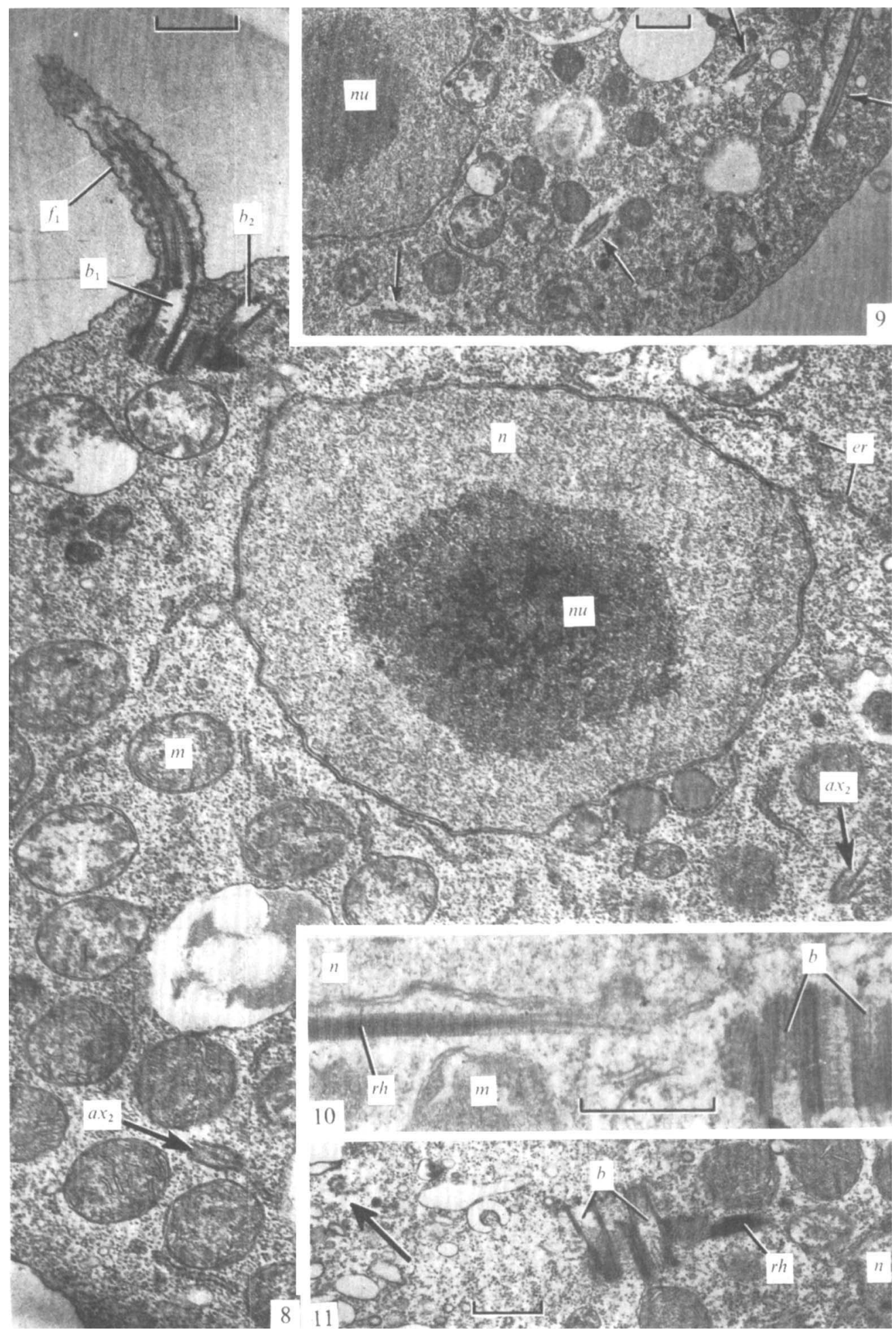


continued, as it does in Amoeba proteus (Marsland, 1964). Although our experiments gave no evidence of multiplication in high concentrations of $\mathrm{D}_{2} \mathrm{O}$, no significance should be attached to this, as the cells were not fed. The most remarkable effect of heavy water on Naegleria was its action on interconversions between the active phenotypes, so that a mixed population of amoebae and flagellates could be converted to amoebae alone and kept in that form.

That $\mathrm{D}_{2} \mathrm{O}$ would induce a rapid reversion from the flagellate stage was unforeseen when the experiments were started. In a number of circumstances $\mathrm{D}_{2} \mathrm{O}$ enhances the stability of transient cytoplasmic structures based on microtubules, such as the mitotic spindle (Inoue \& Sato, 1967), axopods (Tilney, 1968; Marsland, Tilney \& Hirschfield, 1971) and Amoeba gel structures (Marsland, I964), and heavy water was first employed by us in an attempt to reduce the lability of Naegleria flagellates. Why instead it greatly increased this lability is not clear, but the action presumably reflects the differing structural basis for the two forms. The shape of the flagellate is fairly constant and in the absence of a substantial microtubular corset, such as encountered for example in Trypanosoma spp. (Rudzinska \& Vickerman, I968), it would seem to be maintained in part by the state of the cytoplasm. The quiescent cytoplasm of the flagellate contrasts strikingly with the active streaming found in the amoeba and raises intriguing questions about the disposition and cellular control of the actomyosin-like components (Lastovica \& Dingle, 1971) in these two phenotypes.

Although the flagellate stage will revert spontaneously and is sensitive to a number of stresses such as temperature shock, shearing forces, or high pressure (Todd, 1972), as far as we know no agent has yet been reported which will give a reversion as synchronous as that induced by $\mathrm{D}_{2} \mathrm{O}$. At a cytological level, three effects may be relevant to the reversion process. The first is the change in locomotory pattern, which might be effected either by an action on the flagella or on their co-ordinating system. There seems to be a second effect, on the surface membrane of the cell. Several changes are noticed which are manifestations of this: the protrusion of pseudopodia; the ability to settle and move on the substrate; and the permission of penetration of the surface by flagella which happen to strike it. A third change in the cell is the onset of cytoplasmic streaming which accompanies the formation of pseudopodia. Whether any of these visible changes is the initial event is not entirely certain, but the first sign of reversion is the alteration of locomotory pattern.

The glass bead column technique for the production of flagellates gave a suitably homogeneous population for the study of the reversion process. Pittam (1963) reported that on reversion, flagella could enter the cell, and from writhing movements within the cytoplasm he was able to infer that the flagellar beat continued for some time. Dingle \& Fulton (I966) encountered occasional intracytoplasmic axonemes in their study of the developing masti-

Fig. 8 to I I. Electron micrographs of Naegleria gruberi flagellates fixed to min after exposure to the stated doses of $\mathrm{D}_{2} \mathrm{O}$. Scale markers represent $0.5 \mu \mathrm{m}$.

Fig. 8. Seventy-eight per cent $\mathrm{D}_{2} \mathrm{O}$. This cell at an early stage of reversion possesses two flagella, one of which is external; the other, devoid of its surrounding membrane, exists as a naked axoneme visible within the cytoplasm at two points in the section.

Fig. 9. Seventy-eight per cent $\mathrm{D}_{2} \mathrm{O}$. The axonemes of formerly external flagella are embedded now in the cytoplasm.

Fig. 10. Thirty-eight per cent $\mathrm{D}_{2} \mathrm{O}$. Note the close spatial relationship between the rhizoplast and the nuclear envelope.

Fig. Ir. Seventy-eight per cent $\mathrm{D}_{2} \mathrm{O}$. Here at a late stage in reversion the flagella have been withdrawn and the basal bodies, no longer located at the cell periphery, lie deep in the cytoplasm. The structural integrity of the axonemes is breaking down. 
gont system, but considered that this represented a stage in flagellar reversion, rather than in assembly as had been suggested earlier by Schuster (I963). In our studies on uniform populations of reverting flagellates, both light and electron microscopy confirmed the presence of intracytoplasmic axonemes as a stage in the loss of the kinetic apparatus. As we encountered only naked intracytoplasmic axonemes, it seems likely that during their lateral resorption flagellar membranes fused with and became incorporated into the cell membrane. This presumably reflected a recent membrane change, since there was no fusion on random contact between the flagellar and surface membranes of an active flagellate.

The nature of deuterium isotope effects on biological macromolecules is complex and several different modes of action may be distinguished. There is a solvent effect, in which the composition of isotopes in the medium is changed. With $\mathrm{D}_{2} \mathrm{O}$, this also means that the medium is more structured than ordinary water (Némethy \& Scheraga, 1964), which can affect the aggregation of proteins (Khalil \& Lauffer, 1967). Primary and secondary isotope effects will occur where ${ }^{2} \mathrm{H}$ has replaced ${ }^{1} \mathrm{H}$ elsewhere. If a $\mathrm{C}-\mathrm{D}, \mathrm{O}-\mathrm{D}$ or $\mathrm{N}-\mathrm{D}$ bond is formed near the active centre of an enzyme or the labile portion of its substrate, the effect is primary; if the substitution is not near the centre, it is termed secondary although it may still exert some influence on reactions involving that centre (Collins \& Bowman, 1970). Since, however, biological macromolecules have a great deal of exchangeable hydrogen, it is not always easy to distinguish between solvent and other effects, especially in an intact organism. Many properties of proteins will be altered by deuteration; for example, if ${ }^{2} \mathbf{H}$ replaces ${ }^{1} \mathrm{H}$ in a dissociating group, the $\mathrm{pK}$ value will be changed. Nor can ready predications be made about changes in protein configuration, as Tomita, Rich, de Lozé \& Blout (I962) have pointed out in their discussion on the stability of the deuterated $\alpha$-helix. We can say little at this stage, therefore, about the exact mode of action of deuterium oxide on Naegleria gruberi.

As reverted amoebae are able to retransform only when suspended in $\mathrm{H}_{2} \mathrm{O}, \mathrm{D}_{2} \mathrm{O}$ is a useful agent for the easy manipulation of the mobile phenotypes of Naegleria. Combined with availability of homogeneous populations of flagellates from the column, the biochemistry of reversion is now amenable to investigation. The lack of an effect of cycloheximide suggests that there is no requirement for protein synthesis during this rapid process. In contrast, when reverted cells are induced to retransform back to flagellates, they are as sensitive as fresh amoebae to antibiotic inhibitors of RNA and protein synthesis, which would seem to indicate that there is no large-scale storage of flagellar components and that the production of at least some of these depends on de novo synthesis.

We are grateful to Dr R. Bywater for a helpful discussion, and to Miss Eva Crawley for assistance with the photography.

\section{REFERENCES}

Balamuth, W. (1965). Amoebo-flagellate transformation as a model of reversible cyto-differentiation. In Progress in Protozoology, p. 40. Amsterdam: Excerpta Medica Foundation.

CHANG, S. L. (1958). Cytological and ecological observations on the flagellate transformation of Naegleria gruberi. Journal of General Microbiology 18, 579-585.

Collins, C. J. \& Bowman, N. S. (1970). Isotope Effects in Chemical Reactions. American Chemical Society Monograph. New York: Van Nostrand Reinhold.

Dingle, A. D. \& Fulton, C. (1966). Development of the flagellar apparatus of Naegleria. Journal of Cell Biology 31, 43-54.

Flaumenhaft, E., Bose, S., Crespi, H. L. \& Katz, J. (I965). Deuterium isotope effects in cytology. International Review of Cytology 18, 31 3-361. 
Fulton, C. (1970). Amebo-flagellates as research partners: the laboratory biology of Naegleria and Tetramitus. In Methods in Cell Physiology, vol. IV, pp. 341-476. Edited by D. M. Prescott. New York: Academic Press.

Gaw, H. (1936). Physiology of the contractile vacuole in ciliates. 4. The effect of heavy water. Archiv für Protistenkunde 87, 2 I 3-224.

InOuÉ, S. \& Sato, H. (1967). Cell motility by labile association of molecules. The nature of mitotic spindle fibers and their role in chromosome movement. Journal of General Physiology 50, 259-288.

KATZ, J. J. \& CRESPI, H. L. (1970). Isotope effects in biological systems. In Isotope Effects in Chemical Reactions, pp. 286-363. Edited by C. J. Collins and N. S. Bowman. American Chemical Society Monograph. New York: Van Nostrand Reinhold.

KhaliL, M. T. M. \& Lauffer, M. A. (1967). Polymerization - depolymerization of tobacco mosaic virus protein. X. Effect of $\mathrm{D}_{2} \mathrm{O}$. Biochemistry 6, 2474-2480.

Kitching, J. A. \& PAdfield, J. E. (I960). The physiology of contractile vacuoles. XI. Effects of heavy water on the water balance of a suctorian. Journal of Experimental Biology 37, 73-80.

LastovicA, A. J. \& Dingle, A. D. (I97I). Superprecipitation of an actomyosin-like complex isolated from Naegleria gruberi amoebae. Experimental Cell Research 66, 337-345.

MARSLAND, D. (1964). Pressure - temperature studies on amoeboid movement and related phenomena: an analysis of the effects of heavy water $\left(\mathrm{D}_{2} \mathrm{O}\right)$ on the form, movement, and gel structure of Amoeba proteus. In Primitive Motile Systems in Cell Biology, pp. 173-I87. Edited by R. D. Allen and N. Kamiya. New York: Academic Press.

Marsland, D., Tilney, L. G. \& Hirschfield, M. (197I). Stabilizing effects of $\mathrm{D}_{2} \mathrm{O}$ on the microtubular components and needle-like form of heliozoan axopods: a pressure-temperature analysis. Journal of Cellular Physiology 77, I87-193.

Némethy, G. \& ScheraGA, H. A. (I964). Structure of water and hydrophobic bonding in proteins. IV. The thermodynamic properties of liquid deuterium oxide. Journal of Chemical Physics 4I, 680-689.

PitTam, M. D. (1963). Studies of an amoebo-flagellate, Naegleria gruberi. Quarterly Journal of Microscopical Science 104, 513-529.

Preston, T. M. \& O’Dell, D. S. (1971). Synergistic effect of polymixin B with other antibiotics on the transformation of Naegleria gruberi. Experimental Cell Research 68, 465-466.

Rudzinska, M. A. \& Vickerman, K. (I968). The fine structure. In Infectious Blood Diseases of Man and Animals, vol. I, pp. 217-306. Edited by D. Weinman and M. Ristic. New York: Academic Press.

SCHuster, F. (1963). An electron microscope study of the amoebo-flagellate, Naegleria gruberi (Schardinger). I. The amoeboid and flagellate stages. Journal of Protozoology 10, 297-313.

Thomson, J. F. (1963). Biological Effects of Deuterium. Oxford: Pergamon Press.

TILNEY, L. G. (I968). The assembly of microtubules and their role in the development of cell form. Developmental Biology (Suppl. 2), pp. 63-102.

TodD, S. R. (1972). Effects of high hydrostatic pressure on transformation in Naegleria gruberi. Society for Experimental Biology Symposium 26, 485-486.

Tomita, K., Rich, A., De Lozé, C. \& Blout, E. R. (1962). The effect of deuteration on the geometry of the $\alpha$-helix. Journal of Molecular Biology 4, 83-92.

WARren, L., Glick, M. C. \& NASS, M. K. (I966). Membranes of animal cells. I. Methods of isolation of the surface membrane. Journal of Cellular Physiology 68, 269-288.

YuYAMA, S. (I97I). The effects of selected chemical agents on the amoeba-flagellate transformation in Naegleria gruberi. Journal of Protozoology 18, 337-343. 